\title{
KAJIAN PENGGUNAAN OBAT HIPOGLIKEMIK ORAL PADA PASIEN DIABETES MELLITUS TIPE 2 DI PUSKESMAS TEMINDUNG SAMARINDA
}

\author{
Adam M. Ramadhan, Laode Rijai, Jeny Maryani Liu \\ Laboratorium Penelitian dan Pengembangan FARMAKA TROPIS Fakultas Farmasi \\ Universitas Mulawarman, Samarinda, Kalimantan Timur \\ email: adam@farmasi.unmul.ac.id
}

\begin{abstract}
ABSTRAK
Telah dilakukan penelitian dengan judul Kajian Penggunaan Obat Hipoglikemik Oral pada Pasien Diabetes Mellitus Tipe 2 di Puskesmas Temindung Samarinda. Penelitian ini bertujuan untuk mengetahui besarnya persentase tingkat kepatuhan pasien DM tipe 2 dalam penggunaan Obat Hipoglikemik Oral (OHO), mengetahui bahwa pasien DM tipe 2 telah memenuhi kriteria tepat obat dan tepat dosis pada penggunaan $\mathrm{OHO}$ di Puskesmas Temindung. Penelitian ini bersifat analitik observasional, pengambilan data dilakukan secara cross sectional pada pasien diabetes mellitus tipe 2 yang memenuhi kriteria inklusi. Data ini diambil pada bulan Juni hingga Juli 2014. Analisa penelitian ini meliputi kategori tepat obat, tepat dosis dan kepatuhan pasien. Analisis data selanjutnya dilakukan secara analitik dengan menghitung persentase kategori yang diambil. Obat yang digunakan adalah dari golongan biguanid dan sulfonilurea. Obat dari golongan biguanid adalah metformin $500 \mathrm{mg}$. Dari golongan sulfonilurea adalah glibenklamid $5 \mathrm{mg}$ dan glimepirid $2 \mathrm{mg}$. Obat yang telah digunakan memenuhi kriteria tepat obat dan tepat dosis. Sebagian besar pasien dengan persentase $60 \%$ memiliki tingkat kepatuhan yang rendah.
\end{abstract}

Kata Kunci: Diabetes mellitus, DM tipe 2, Obat Hipoglikemik Oral (OHO)

\section{PENDAHULUAN}

Diabetes mellitus (DM) menurut American Diabetes Association (ADA) 2005 merupakan suatu kelompok penyakit metabolik dengan karakteristik hiperglikemia yang terjadi karena kelainan sekresi insulin, kerja insulin atau kedua-duanya. Hiperglikemia kronik pada diabetes berhubungan dengan kerusakan jangka panjang, disfungsi atau kegagalan beberapa organ tubuh terutama mata, ginjal, saraf, jantung dan pembuluh darah (Soegondo, 2009).

Berdasarkan penelitian yang dilakukan oleh International Diabetes Federation (IDF) tahun 2003, menyatakan bahwa prevalensi diabetes mellitus di dunia adalah $5,1 \%$ atau sekitar 194 juta penduduk menderita diabetes mellitus pada kelompok umur
20 sampai 79 tahun. Angka ini diperkirakan akan meningkat menjadi sekitar 333 juta orang pada tahun 2025 atau prevalensi sekitar 6,3\% populasi dewasa dunia (Goldstein dan Muller, 2008).

Kriteria diagnosis diabetes mellitus adalah terdapat gejala DM dan kadar random plasma glukosa sebesar $\geq$ $200 \mathrm{mg} / \mathrm{dl}$, kadar glukosa puasa $\geq 126$ $\mathrm{mg} / \mathrm{dl}$, kadar glukosa 2 jam setelah tes toleransi glukosa $\geq 200 \mathrm{mg} / \mathrm{dl}$ dan kadar glikosilat hemoglobin atau $\mathrm{HbA}_{1} \mathrm{C} \geq 8 \%$ (Priyanto, 2008).

\section{METODE PENELITIAN}

\section{Instrumen Penelitian}

Kuisioner kepatuhan Medication Morisky Adherence Scale-8 (MMAS-8), 
kartu rekam medik pasien dan lembar pengumpul data.

\section{Populasi dan Subjek Penelitian}

Populasi dari penelitian ini adalah penduduk yang mengalami DM tipe 2 di wilayah kerja Puskesmas Temindung Samarinda pada periode bulan Juni hingga Juli 2014. Subjek dari penelitian ini adalah responden yang diberikan obat hipoglikemik oral oleh petugas kesehatan Puskesmas di wilayah kerja Puskesmas Temindung Samarinda yang berkunjung ke Poli Umum pada periode bulan Juni hingga Juli 2014 yang memenuhi kriteria inklusi.

\section{Prosedur Penelitian}

Penelitian diawali dengan melakukan survei pendahuluan pada Poli Umum di Puskesmas Temindung
Samarinda. Pasien yang memenuhi kriteria inklusi, diwawancarai dengan menggunakan kuisioner MMAS-8. Data yang telah didapat kemudian dikumpulkan untuk diolah dan dianalisa..

\section{HASIL DAN PEMBAHASAN}

\section{Pola Pengobatan}

Penelitian ini dilakukan di Puskesmas Temindung Samarinda. Data yang diperoleh dari kuisioner kepatuhan dan rekam medik berjumlah 30 pasien. Selanjutnya dianalisis penggunaan obat berdasarkan tepat obat, tepat dosis, dan kepatuhan pasien dalam meminum obat hipoglikemik oral.

Pola Pengobatan penderita DM Tipe 2 di Puskesmas Temindung dapat dilihat pada tabel 1. dan tabel 2.

Tabel. 1. Pola pengobatan pasien DM tipe 2 di Puskesmas Temindung dengan Obat Hipoglikemik Oral Tunggal

\begin{tabular}{lccc}
\hline Golongan Obat & Obat & Frekuensi & Persentase \\
\hline \multirow{2}{*}{ Sulfonilurea } & Glibenkalmid & 15 & $50 \%$ \\
Biguanid & Glimepirid & 2 & $6,7 \%$ \\
\hline
\end{tabular}

Tabel 2. Pola pengobatan pasien DM tipe 2 di Puskesmas Temindung dengan Obat Hipoglikemik Oral Kombinasi

\begin{tabular}{lccc}
\hline Golongan Obat & Obat & Frekuensi & Persentase \\
\hline \multirow{2}{*}{ Biguanid+Sulfonilurea } & Metformin-Glibenklamid & 10 & $33,3 \%$ \\
& Metformin-Glimepirid & 1 & $3,3 \%$ \\
\hline
\end{tabular}

Berdasarkan tabel 1 . menunjukkan bahwa penggunaan obat hipoglikemik oral yang paling sering digunakan adalah obat dari golongan sulfonilurea sebesar $56,7 \%$, selanjutnya obat kombinasi menempati urutan ke-2 yakni sebesar $36,6 \%$ dan obat dari golongan biguanid sebesar $6,7 \%$. Metformin digunakan sebagai lini pertama dalam penatalaksanaan DM tipe 2, namun ketika terjadi efek samping yaitu gangguan gastrointestinal maupun kadar glukosa darah tidak mencapai target yang diinginkan, biasanya diganti dengan obat tunggal lainnya dari golongan sulfonilurea.

\section{Kriteria Tepat Obat}

Ketepatan obat pasien DM tipe 2 di Puskesmas Temindung dapat dilihat dari pola pengobatan yang diberikan. Tabel 3. dan 4. merupakan perbandingan antara pola pengobatan pasien DM tipe 2 berdasarkan literatur yaitu PERKENI 2011 dengan pola pengobatan DM tipe 2 di Puskesmas Temindung Samarinda. 
Tabel 3. Pola Pengobatan DM tipe 2 (dalam PERKENI, 2011)

\begin{tabular}{|c|c|c|}
\hline Kategori & Golongan Obat & Jenis \\
\hline \multirow{6}{*}{ Obat Tunggal } & Biguanid & Metformin \\
\hline & Sulfonilurea & $\begin{array}{l}\text { Glibenklamid, Glimepirid, } \\
\text { Tolbutamid, Klorpropamid. }\end{array}$ \\
\hline & Glinid & Repaglinid \\
\hline & Tiazolidinedion & Pioglitazone, Rosiglitazone \\
\hline & $\begin{array}{l}\text { Penghambat alfa } \\
\text { glukosidase }\end{array}$ & Acarbose, Miglitol \\
\hline & DPP-IV inhibitor & Vildagliptin \\
\hline \multirow{3}{*}{ Obat Kombinasi } & Biguanid+Sulfonilurea & Metformin+Glibenklamid \\
\hline & & Metformin+Glimepirid \\
\hline & Biguanid+Tiazolidinedion & Metformin+Pioglitazone \\
\hline
\end{tabular}

Tabel 4. Pola pengobatan pasien DM tipe 2 di Puskesmas Temindung Samarinda

\begin{tabular}{lc}
\hline Golongan Obat & Obat \\
\hline Sulfonilurea & Glibenkalmid \\
Biguanid & Glimepirid \\
Biguanid+Sulfonilurea & Metformin \\
& Metformin-Glibenklamid \\
\hline
\end{tabular}

Berdasarkan data yang telah dipaparkan sebelumnya, bahwa sebagian besar pasien menggunakan obat yang berasal dari golongan sulfonilurea. Meskipun algoritma terapi DM tipe 2 menunjukkan obat dari golongan biguanid sebagai lini pertama dalam pengobatan DM tipe 2, setelah dilakukan pemeriksaan 2-3 bulan selanjutnya, kondisi kadar glukosa darah pasien masih berada di atas normal dan beberapa pasien mengeluhkan gangguan gastrointestinal saat menggunakan metformin, sehingga obat selanjutnya yang digunakan adalah obat yang berasal dari golongan sulfonilurea. Meskipun beberapa literatur menyebutkan bahwa kondisi lansia berpotensi mengalami hipoglikemia setelah pemberian sulfonilurea, hal ini dapat dicegah dengan menginformasikan kepada pasien mengenai pertolongan pertama pada kondisi hipoglikemia. Akan tetapi berdasarkan penelitian di lapangan, sebagian besar pasien tidak mengalami kondisi hipoglikemia setelah penggunaan obat sulfonilurea. Setelah pemberian sulfonilurea, beberapa pasien menunjukkan penurunan kadar glukosa darah yang baik dan tidak mengeluhkan kondisi hipoglikemia sehingga penggunaan obat dari golongan ini dapat dianggap tepat obat.

Penggunaan obat kombinasi menempati urutan kedua terbanyak. Hal ini disebabkan oleh kadar glukosa darah pasien yang tidak menurun ketika diberikan obat tunggal. Hal ini menunjukkan bahwa penggunaan obat kombinasi dianggap tepat atau sesuai dengan algoritma terapi DM tipe 2, apabila kadar glukosa darah pasien tetap 
tidak normal setelah pemberian obat tunggal, maka diberikan obat kombinasi.

\section{Kriteria Tepat Dosis}

Kriteria tepat dosis diperoleh dengan menghubungkan antara dosis yang dianjurkan dalam literatur dengan dosis yang diberikan pada pasien DM tipe 2 di Puskesmas Temindung Samarinda. Berikut merupakan tabel perbandingan dosis obat hipoglikemik oral dalam PERKENI dengan dosis obat yang digunakan oleh pasien DM tipe 2 di Puskesmas Temindung Samarinda.

Tabel 5. Dosis Obat Hipoglikemik Oral (dalam PERKENI, 2011)

\begin{tabular}{cccccc}
\hline No. & Obat & Dosis & Dosis Maksimal & Frekuensi & Durasi Kerja \\
\hline 1. & Metformin & $500 \mathrm{mg}$ & $3000 \mathrm{mg}$ & $1-3$ kali sehari & $6-8$ jam \\
2. & Glibenklamid & $5 \mathrm{mg}$ & $15 \mathrm{mg}$ & 1 kali sehari & $12-24$ jam \\
3. & Glimepirid & $2 \mathrm{mg}$ & $6 \mathrm{mg}$ & 1 kali sehari & 24 jam \\
\hline
\end{tabular}

Tabel 6. Pola dosis OHO yang diberikan kepada pasien DM tipe 2 di Puskesmas Temindung

\begin{tabular}{clcc}
\hline No. & \multicolumn{1}{c}{ Obat } & Dosis & Frekuensi \\
\hline 1. & Glibenklamid & $5 \mathrm{mg}$ & Sekali sehari \\
2. & Metformin & $500 \mathrm{mg}$ & 3 kali sehari \\
3. & Glimepirid & $2 \mathrm{mg}$ & Sekali sehari \\
\hline
\end{tabular}

Tabel 7. Tingkat Kepatuhan Pasien DM tipe 2 di Puskesmas Temindung.

\begin{tabular}{lcc}
\hline \multicolumn{1}{c}{ Tingkat Kepatuhan } & Jumlah & Persentase \\
\hline Kepatuhan Rendah & 18 & $60 \%$ \\
Kepatuhan Tinggi & 12 & $40 \%$ \\
\hline
\end{tabular}

Berdasarkan tabel 5. dan 6., penggunaan dosis obat hipoglikemik oral di Puskesmas Temindung Samarinda telah sesuai dengan literatur. Rentang dosis Metformin adalah $500 \mathrm{mg}$ sampai $3000 \mathrm{mg}$, dengan durasi kerja 6-8 jam dan frekuensi pemberian 1 sampai 3 kali sehari, menurut literatur metformin digunakan bersama makanan atau setelah makan untuk mencegah terjadinya efek samping yaitu gangguan gastrointestinal. glibenklamid memiliki rentang dosis 5 mg hingga $15 \mathrm{mg}$ dengan frekuensi pemberian sekali sehari, dan durasi kerja 12-24 jam. glimepirid memiliki rentang dosis $2 \mathrm{mg}$ hingga $6 \mathrm{mg}$, dengan durasi 24 jam dan frekuensi pemberian sekali sehari. Pada pengobatan kombinasi antara metformin dengan sulfonilurea, mula-mula diberikan 1 tablet Metformin $500 \mathrm{mg}$, dosis dinaikkan perlahan-lahan sampai diperoleh kontrol optimal. Dosis sulfonilurea dapat dikurangi, pada beberapa pasien bahkan tidak perlu diberikan lagi. Pengobatan dapat dilanjutkan dengan metformin sebagai obat tunggal.

\section{Kepatuhan Pasien}

Tingkat kepatuhan pasien diperoleh dengan menggunakan kuisioner dan wawancara langsung kepada pasien yang memenuhi kriteria inklusi. Distribusi pasien hipertensi di Puskesmas Temindung Samarinda berdasarkan tingkat kepatuhannya disajikan dalam tabel 7. Dan gambar 1.

Berdasarkan tingkat persentase, terlihat bahwa tingkat kepatuhan pasien sebagian besar masih rendah. Secara teori, kepatuhan pasien dalam menggunakan obat pada pasien DM tipe 2 memiliki hubungan yang signifikan terhadap tingkat kadar glukosa darah pada pasien diabetes mellitus. Dimana semakin tinggi tingkat kepatuhan pasien, 
maka semakin baik kadar glukosa darah pasien atau semakin mencapai nilai normal. Berdasarkan data yang ada, sebagian besar pasien dengan tingkat kepatuhan yang rendah memiliki kadar glukosa masih tinggi atau melebihi kadar normal. Hal ini menunjukkan kesesuaian antara data dengan teori yang ada. Selanjutnya, sebanyak 12 pasien dengan tingkat kepatuhan yang tinggi memiliki nilai kadar glukosa darah yang masih diatas normal. Hal ini dapat disebabkan oleh beberapa hal, antara lain data kadar glukosa yang diperoleh bukan merupakan data yang terbaru sehingga terjadi perbedaan waktu antara saat pengisian kuisioner dengan saat pemeriksaan kadar glukosa darah, dan pasien yang tidak melakukan gaya hidup sehat yang tepat.

Alasan terbesar pasien menjadi tidak patuh berdasarkan hasil wawancara dan menggunakan kuisioner MMAS-8, diberikan pada Tabel 8.

Tabel 8. Alasan ketidakpatuhan pasien dalam penggunaan obat

\begin{tabular}{llc}
\hline No. & \multicolumn{1}{c}{ Alasan } & Jumlah \\
\hline 1. & Pasien terkadang lupa meminum obat & 17 pasien \\
2. & $\begin{array}{l}\text { Pasien merasa tidak nyaman atau terganggu } \\
\text { dengan kewajiban meminum obat }\end{array}$ & 16 pasien \\
3. & $\begin{array}{l}\text { Sebagian besar mengaku sesekali kesulitan dalam } \\
\text { mengingat penggunaan obat }\end{array}$ & 16 pasien \\
\hline
\end{tabular}

Berdasarkan alasan yang telah dipaparkan, maka perlunya dilakukan sosialisasi yang lebih mengenai manfaat penggunaan $\mathrm{OHO}$ secara teratur. Peran serta petugas kesehatan dalam mensosialisasikan masih dibutuhkan dan peran serta keluarga untuk membantu pasien dalam menggunakan obat secara teratur serta mengatur pola makan dan gaya hidup yang sehat akan menolong pasien untuk meningkatkan kualitas hidup pasien DM tipe 2.

Penelitian yang telah dilakukan masih banyak terdapat kekurangan, antara lain masih perlunya dilakukan sosialisasi yang lebih lanjut kepada pasien maupun keluarga pasien mengenai kepatuhan pasien dalam menggunakan obat dan faktor yang menyebabkan kadar glukosa darah pasien tidak mencapai goal therapy atau tidak terkontrol, perlu dilakukan penelitian kembali di Puskesmas Temindung untuk mengkaji lebih lanjut mengenai peningkatan pengetahuan dan kepatuhan pasien dalam menjalankan pengobatannya dan dihubungkan dengan kadar glukosa darah pasien terbaru dan jumlah pasien yang menjadi sampel terlalu sedikit untuk dijadikan sampel penelitian, serta tanggal kadar glukosa darah yang diperoleh tidak sesuai dengan tanggal wawancara kuisioner sehingga dikhawatirkan terjadi bias yang terlalu besar.

\section{KESIMPULAN}

Pola penggunaan obat hipoglikemik oral pada pasien hipertensi di Puskesmas Temindung Samarinda berdasarkan golongan obat yang diberikan yaitu Biguanid dan Sulfonilurea. Ketepatan obat dan dosis yang diberikan telah sesuai dengan PERKENI.

\section{UCAPAN TERIMA KASIH}

Penulis mengucapkan terima kasih kepada Pimpinan Puskesmas Temindung Samarinda atas izin penelitian. Terima kasih kepada dr. Yuna selaku pendamping lapangan, dr. Ona, dr. Karin, dr. Randy atas bantuan selama penelitian. 


\section{DAFTAR PUSTAKA}

1. Anonim. 2005. Pharmaceutical Care untuk Penyakit Diabetes Mellitus. Jakarta: Departemen Kesehatan RI

2. Budiharto. 2008. Metodologi Penelitian Kesehatan. Jakarta: EGC

3. Goldstein, B. J., Muller D. 2008. Type 2 Diabetes Principles and Practice Second Edition. New York: Informa Healthcare

4. Morisky D.E., Krousel-Wood M, Ward H. 2008. Predictive validity of a medication adherence measure for hypertension control. $J$ Clin Hypertens; 10:384-354
5. Oates, Jhon A., Grant R. Wilkinson. 1995. Farmakologi Klinis dalam: Isselbacher, Kurt J., Ahmad $H$. Asdie. Harrison Prinsip-Prinsip Ilmu Penyakit Dalam. Jakarta: EGC

6. Priyanto. 2008. Farmakologi dan Terminologi Medis. Jakarta: Leskonfi 